\title{
Decision Making and Management in Pediatric Cervical Spine Injuries
}

\author{
Vibhu Krishnan Viswanathan* and Surabhi Subramanian \\ Clinical Spine Fellow, Ohio State University, USA
}

Submission: June 04, 2017; Published: June 08, 2017

*Corresponding author: Vibhu Krishnan Viswanathan, Clinical Spine Fellow, Ohio State University, Columbus, Ohio - 43202, USA,

Tel: +16143023859; Email: drvibu007@gmail.com

\begin{abstract}
Pediatric cervical spine injuries are rare. However, these injuries are known to be associated with significant mortality. These injuries are significantly different from cervical spine injuries (CSI) in adults, both in terms of injury patterns and clinical presentation. In the current article, the approach to such injuries, diagnostic dilemma encountered and management rationales have been comprehensively discussed.

Keywords: Pediatric cervical spine injuries; Radiological evaluation; SCIWORA

Abbreviations: CSIs: Cervical Spine Injuries; NEXUS: National Emergency X-Ray Utilization Study; CT: Computerised Tomography; SCIWORA: Spinal Cord Injury Without Radiographic Abnormality; OAAI: Occipitoatlantal and Atlantoaxial Instability; AARF: Atlantoaxial Rotatory Fixation; STIR: Short T1-Weighted Inversion Recovery
\end{abstract}

\section{Introduction}

Pediatric cervical spine injuries (CSIs) are rare [1]. Nevertheless, their significance cannot be understated, considering the peculiarities of injury patterns, clinical presentation, diagnostic dilemma and management of these injuries, in comparison to the adult counterparts [2]. They also contribute to a significant proportion of morbidity and mortality in the pediatric patients [1]. The approach to these injuries is significantly different from adult cervical spinal injuries [3].

\section{Patterns of CSI}

CSIs are the most common level for pediatric spinal injuries [4]. Dislocations and ligament ruptures are the mode of injury in $44 \%$ of patients [5]. Majority of the injuries in children occur at levels between occiput and C4 vertebra [1]. Factors including large size of head, highly flexible cervical spine, poorly developed musculature, ligamentous laxity and immature bony vertebrae predispose pediatric cervical spine to injuries $[1,6,7]$. When a child is suspected to have cervical spine injury (based on the mode of injury, symptoms, conditions predisposing to spinal injury like rheumatoid disorders and associated high risk injuries), radiological evaluation involving 3-view radiographs (AP, lateral and open-mouth AP cervical views) need to be performed [7].

The two major clinical criteria NEXUS (National Emergency X-Ray Utilization Study) and CCR (Canadian Cervical Spine
Rule), which are extremely useful in adults, are not proven to be sufficient to rule out pediatric CSI [8]. The normal radiological variants on plain X-rays in pediatric spine (hypolordosis, C2-3 pseudosubluxation, non-ossified vertebral bone) need to be borne in mind [9,10]. Computerised Tomography (CT) scan needs to be performed only in a child with any evidence of bony injury on plain X-ray or when plain radiograph is normal in a child with high suspicion for CSI [11]. MRI scan is performed whenever abnormal neurological findings are elicited, especially when other imaging studies are inconclusive [12]. Spinal Cord Injury without Radiographic Abnormality (SCIWORA) is defined in children as a situation when neurological deficit is evident in the absence of obvious abnormality on plain radiographs or CT scan. However, in most cases of SCIWORA, injuries to spinal cord or ligaments may be demonstrable [13].

\section{Specific Injury patterns in children and their management}

a. Occipitoatlantal and atlantoaxial Instability (OAAI): Occipitoatlantoaxial complex injuries can result from distraction injuries, leading to significant instability [14]. Complete neurological deficit can cause immediate death. Traction and cervical collar need to be avoided as they can lead to overdistraction [15]. Definitive treatment of these injuries is surgical fusion [14]. 
b. Atlantoaxial Rotatory Fixation (AARF): These injuries have been described to arise out of pathological sickness of C1-2 joint and the patients typically present with a fixed torticollis [16]. They are radiologically classified on the basis of progressive severity: degrees of disruption of transverse atlantal and alar ligaments [17]. Delayed presentations usually lead to chronic adherence and usually requires multi-staged management including halo traction, halo-vest application with or without surgical fusion $[16,17]$.

c. Odontoid fractures: These are avulsions of synchondrosis between dens and C2 body, which are typically seen in children less than 7 years. Being epiphyseal injuries, these fractures usually heal adequately on halo-immobilization, although surgical fusion may be considered in delayed presentation [18].

d. Sub-axial ligamentous injury: These are rare injuries in young patients $(<8$ years). Although Short T1-weighted Inversion Recovery (STIR) sequences delineate the soft tissue injuries best, instability is best described on radiographs. Ware et al. [19] suggested that kyphotic deformity as little as $7.5^{\circ}$ can indicate instability in pediatric spine. Soft tissue injuries without radiographic abnormalities can be treated with soft collar. If pain limits proper dynamic Xrays, hard cervical collar can be applied followed by re-evaluation with dynamic films after 2 weeks. Patients with evidence of more substantial soft tissue injuries require careful evaluation and MRI scan. Hard cervical immobilization needs to be employed for non-operative management in such cases with meticulous, radiologic follow-up [20].

Any neuro-deficit mandates surgical fusion. Unilateral and bilateral facet dislocations are relatively common in children. In cases with bilateral dislocation and complete neurodeficit, emergent manual reduction, followed by MRI scan (for evaluation of disc herniation or epidural hematoma) is performed. In patients with incomplete or no motor deficits, MRI scan is initially performed. If no epidural hematoma or disc herniation is evident, closed manual or weighted reduction is performed. This is followed by anterior with or without posterior cervical fusion $[19,20]$.

e. Cervical cord neuropraxia: This is a mild form of SCIWORA occurring in athletes performing contact sports and is commonly called a stinger or spinal cord concussion [21]. In children, such transient injuries can happen even without any pre-existing cervical stenosis owing to the hypermobile cervical spine. A majority of patients recover well with conservative measures involving spinal immobilization with hard cervical collar [22].

\section{References}

1. Cirak B, Ziegfeld S, Knight VM, Chang D, Avellino AM, et al. (2004) Spinal injuries in children. J Pediatr Surg 39(4): 607-612.

2. Booth TN (2012) Cervical spine evaluation in pediatric trauma. AJR Am J Roentgenol 198(5): W417-425.
3. Kokoska ER, Keller MS, Rallo MC, Weber TR (2001) Characteristics of pediatric cervical spine injuries. J Pediatr Surg 36(1): 100-105.

4. Hamilton MG, Myles ST (1992) Pediatric spinal injury: review of 61 deaths. J Neurosurg 77(5): 705-708.

5. Reilly CW, Leung F (2005) Synchondrosis fracture in a pediatric patient. Can J Surg 48(2): 158-159.

6. Roche C, Carty H (2001) Spinal trauma in children. Pediatr Radiol 31(10): 677-700.

7. Mower WR, Hoffman JR, Pollack CV, Zucker MI, Browne BJ, et al. (2001) Use of plain radiography to screen for cervical spine injuries. Ann Emerg Med 38(1): 1-7.

8. Chung S, Mikrogianakis A, Wales PW, Dirks P, Shroff M, et al. (2011) Trauma association of Canada Pediatric Subcommittee National Pediatric Cervical Spine Evaluation Pathway: consensus guidelines. J Trauma 70(4): 873-884.

9. Ehara S, el-Khoury GY, Sato Y (1988) Cervical spine injury in children: radiologic manifestations. AJR Am J Roentgenol 151(6): 1175-1178.

10. Sanchez JI, Paidas CN (1999) Childhood trauma. Now and in the new millennium. Surg Clin North Am 79(6): 1503-1535.

11. Adelgais KM, Browne L, Holsti M, Metzger RR, Murphy SC, et al. (2014) Cervical spine computed tomography utilization in pediatric trauma patients. J Pediatr Surg 49(2): 333-337.

12. Flynn JM, Closkey RF, Mahboubi S, Dormans JP (2002) Role of magnetic resonance imaging in the assessment of pediatric cervical spine injuries. J Pediatr Orthop 22(5): 573-577.

13. Pang D, Wilberger JE (1982) Spinal cord injury without radiographic abnormalities in children. J Neurosurg 57(1): 114-129.

14. Harris MB, Duval MJ, Davis JA, Bernini PM (1993) Anatomical and roentgenographic features of atlantooccipital instability. J Spinal Disord 6(1): 5-10.

15. Dickman CA, Greene KA, Sonntag VK (1996) Injuries involving the transverse atlantal ligament: classification and treatment guidelines based upon experience with 39 injuries. Neurosurgery 38(1): 44-50.

16. Pang D, Li V (2005) Atlantoaxial rotatory fixation: part 2-new diagnostic paradigm and a new classification based on motion analysis using computed tomographic imaging. Neurosurgery 57(5): 941-53; discussion -53 .

17. Pang D, Li V (2005) Atlantoaxial rotatory fixation: part 3-a prospective study of the clinical manifestation, diagnosis, management, and outcome of children with alantoaxial rotatory fixation. Neurosurgery 57(5):954-72; discussion -72.

18. Mandabach M, Ruge JR, Hahn YS, McLone DG (1993) Pediatric axis fractures: early halo immobilization, management and outcome. Pediatr Neurosurg 19(5): 225-232.

19. Gore PA, Chang S, Theodore N (2009) Cervical spine injuries in children: attention to radiographic differences and stability compared to those in the adult patient. Semin Pediatr Neurol 16(1): 42-58.

20. Horn EM, Lekovic GP, Feiz-Erfan I, Sonntag VK, Theodore N (2004) Cervical magnetic resonance imaging abnormalities not predictive of cervical spine instability in traumatically injured patients. Invited submission from the Joint Section Meeting on Disorders of the Spine and Peripheral Nerves, March 2004. J Neurosurg Spine 1(1): 39-42.

21. Torg JS, Corcoran TA, Thibault LE, Pavlov H, Sennett BJ, et al. (1997) Cervical cord neurapraxia: classification, pathomechanics, morbidity, and management guidelines. J Neurosurg 87(6): 843-850.

22. Boockvar JA, Durham SR, Sun PP (2001) Cervical spinal stenosis and sports-related cervical cord neurapraxia in children. Spine (Phila Pa 1976) 26(24):2709-2712; discussion 13. 
This work is licensed under Creative Commons Attribution 4.0 Licens

DOI: 10.19080/OAJS.2017.04.555641

\section{Your next submission with Juniper Publishers} will reach you the below assets

- Quality Editorial service

- Swift Peer Review

- Reprints availability

- E-prints Service

- Manuscript Podcast for convenient understanding

- Global attainment for your research

- Manuscript accessibility in different formats

( Pdf, E-pub, Full Text, Audio)

- Unceasing customer service

Track the below URL for one-step submission https://juniperpublishers.com/online-submission.php 